\title{
Cattle disease faces total wipeout
}

Rinderpest goes the way of smallpox.

What does it take to wipe a scourge off the face of the Earth? A massive global push to hunt down and eradicate the last few stubborn pockets of disease - whether the problem is in people or cattle.

World health bodies say that within 18 months they will celebrate the eradication of rinderpest, the world's most devastating cattle disease. It would become only the second disease that humans have wiped from the globe - after smallpox, which was declared vanquished in 1980 - and will mark a "massive achievement for the veterinary community", says Chris Oura, head of the Non-Vesicular Disease Reference Laboratory Group at the Institute for Animal Health in Pirbright, UK.

"Rinderpest tops the list of killer [animal] diseases," says Juan Lubroth, chief veterinary officer for the Food and Agricultural Organization of the United Nations (FAO) in Rome. Just as smallpox ripped through human populations for centuries, so too has rinderpest drastically reduced animal populations.

Also known as cattle plague, rinderpest can lead to famine when people lose the beasts they need to plough their fields. It first spread from Asia to Europe in the herds of invading tribes, causing outbreaks in the Roman Empire in 376-386, and since then it has killed millions of cattle and other wildlife throughout Europe, Africa, the Middle East and the Indian subcontinent. The world's first veterinary science school was established in France in 1762 to train specialists to deal with rinderpest.

The disease, which can kill 80-90\% of infected cattle within ten days, is caused by a morbillivirus - a group of viruses that also includes measles. Clinical signs include fever, discharges from the eyes and nose, diarrhoea and dehydration.

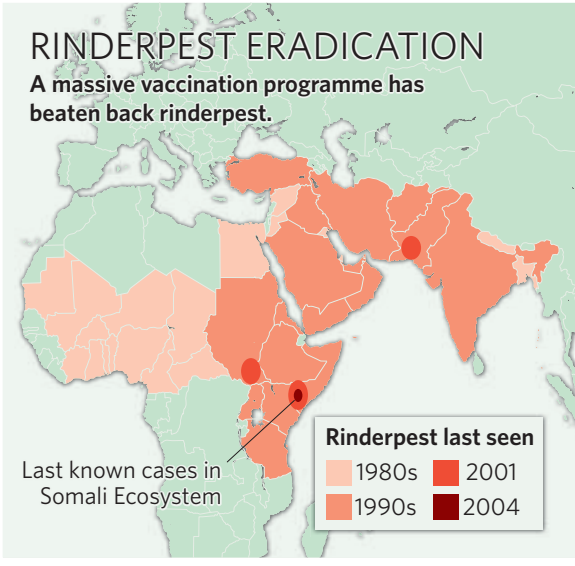

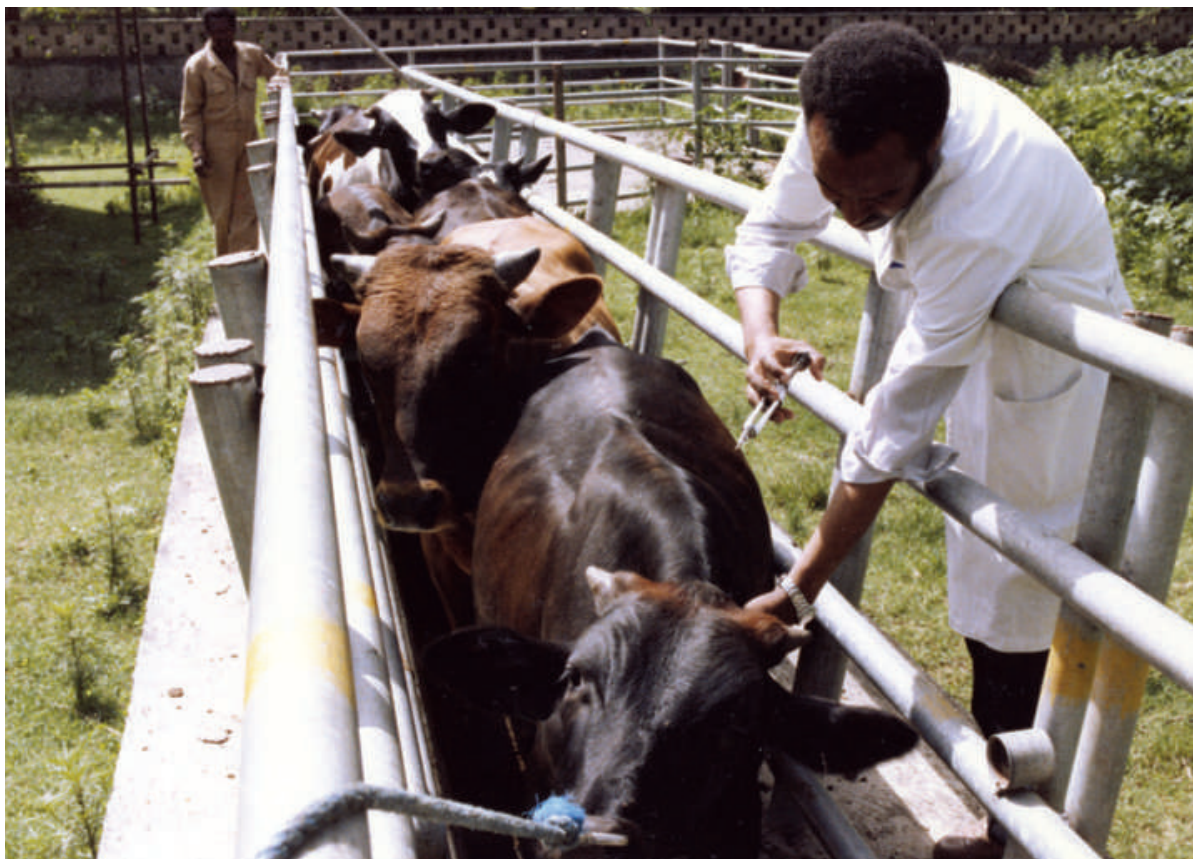

Vaccines developed in the 1980s have helped to control outbreaks of rinderpest around the world.

In the 1980s, outbreaks in Nigeria cost around US $\$ 2$ billion. But that decade also saw a breakthrough in controlling the disease: a vaccine containing the attenuated virus that was heat-stable and could be stored and transported over long distances.

\section{Going global}

In 1994, a global effort to eradicate rinderpest was launched, headed by the FAO and the World Organisation for Animal Health (OIE), based in Paris. It incorporated several earlier, regional efforts and focused on widespread vaccination programmes and on long-term monitoring of cattle and wildlife. The last known outbreak was in Kenya in 2001, with the last remaining pockets of the disease in Pakistan, Sudan and the Somali Ecosystem (parts of Somalia, Ethiopia and Kenya) thought to have been eradicated by 2007 (see map).

Oura says that the biggest scientific challenge in eradicating the virus is the large-scale monitoring and surveillance needed to ensure that the virus is gone. "It's a huge task when you have the virus in developing countries and war zones, such as Somalia, to carry out monitoring and surveillance," he says. By the 1970s, smallpox, too, was found only in the war-torn Horn of Africa, where the last case was isolated in Somalia in 1977.

Although the rinderpest vaccine can provide life-long protection, it also poses a challenge. Because it contains the live virus, diagnostic tests can't differentiate between infected and vaccinated animals, as both will test positive for antibodies against the virus. Cows also pass on antibodies to their offspring through their milk. So, to confirm whether the virus has been eradicated, vaccinations must stop for a period of two years and calves younger than two years old then need to be tested. "It is a difficult, long process to make sure nothing is there," says Oura.

Lubroth says he is "confident" that the world is already free of the disease but that the FAO and the OIE expect to make an official declaration that it has been eradicated in 18 months.

Bernard Vallat, director-general of the OIE, says that the hold-up is because 12 countries are yet to submit their final test and surveillance results to the organization. Even after the disease is declared extinct in the wild, it will live on in the lab. Over the next year and a half, the OIE will be drawing up an inventory of which governments and laboratories around the world are keeping a stock of the virus for research purposes.

Natasha Gilbert 